\begin{tabular}{c}
\hline ANALYTICAL SCIENCE \\
\& TECHNOLOGY
\end{tabular}

http://dx.doi.org/10.5806/AST.2011.24.4.249

\title{
Study on swelling of starch granules using gravitational field-flow fractionation (GrFFF)
}

\author{
Sun Tae Kim, So Yeon Seo and Seungho Lee \\ Department of Chemistry, Hannam University, Daejeon, 305-811 Korea \\ (Received June 28, 2011; Accepted July 8, 2011)
}

\section{중력 장-흐름 분획법을 이용한 전분 입자의 swelling에 관한 연구}

\author{
김선태·서소연 · 이승호` \\ 한남대학교 화학과
}

(2011. 6. 28. 접수, 2011. 7. 8. 승인)

\begin{abstract}
요 약: 물의 흡수에 의한 전분알갱이의 swelling은 물과 친화력이 있는 새로운 부분의 노출에 의하여 구 조적인 변화로써 점진적으로, 때로는 갑작스럽게 변화를 일으킨다. 이러한 이유로 인해서, 물과의 접촉 시간에 따르는 전분 알갱이의 크기 또는 모양의 변화에 관심을 가진다. 중력 장-흐름 분획법(gravitation field-flow fractionation, GrFFF)은 마이크론 범위의 크기를 가지는 입자들을 분리하는 데에 유용한 분리 기술이다. 본 연구에서는 감자와 고구마 전분알갱이들의 크기와 크기 분포도를 결정하는 데에 있어서 $\mathrm{GrFFF}$ 의 응용가능성을 검사하고자 한다. $\mathrm{GrFFF}$ 를 이용하여 물과의 접촉 시간에 따르는 전분 알갱이들 의 크기분포도 변화를 모니터하였다. GrFFF로부터 얻어진 전분알갱이들의 크기 및 크기분포는 광학현미 경(optical microscopy, $\mathrm{OM}$ ) 결과와 비교하였다. 결과적으로 감자와 고구마 전분의 swelling은 물과의 접 촉시간이 증가함에 따라 전분알갱이의 크기가 증가하며, 전분의 종류가 달라지면 swelling 속도가 달라 짐을 확인하였다.
\end{abstract}

Abstract: Swelling of starch granules by water-sorption causes a progressive or sometimes abrupt change in sorption behavior as a result of structural alterations and the possible exposure of new sites with high affinity for water. It is thus of interest to examine the time-dependent change in the size or shape of the starch granules. Gravitational field-flow fractionation (GrFFF) utilizes the earth's gravity as the external field, and is useful for separation of micron-sized particles with larger particles eluting earlier than smaller ones. In this study, GrFFF was used to monitor the swelling of two starch granules, potato starch and sweet potato starch during contact time of 11-12 days at room temperature in water. Results from GrFFF were compared with those obtained from optical microscope $(\mathrm{OM})$. For both starch granules, the mean sizes were increased with time spent in water.

Key words: GrFFF, starch swelling, starch size, particle separation

$\star$ Corresponding author

Phone : +82-(0)42-629-8822 Fax : +82-(0)42-629-8811

E-mail : slee@hnu.kr 


\section{Introduction}

Starch is widely used for various applications in food and pharmaceutical industries and also for technical and biotechnical applications. The shape, size and size distribution of starch granules play critical roles in food fermentation processes. Many studies reported that large granules are more susceptible to chemical and enzymatic hydrolysis and are more useful in food chemistry. ${ }^{1}$

Most starches are composed of two polysaccharides which are amylose and amylopectin, in approximate mass percentages of $15-30 \%$ and $85-70 \%$, respectively. Amylose is a linear molecule of $(1 \rightarrow 4)$ linked $\alpha$-Dglucopyranosyl units. It is known that some molecules are slightly branched by $(1 \rightarrow 6)$ - $\alpha$-linkages. Amylopectin is highly branched component of starch. It is formed through chains of $\alpha$-D-glucopyranosyl residues linked together mainly by $(1 \rightarrow 4)$ linkages but with $5-6 \%$ of $(1 \rightarrow 6)$ bonds at the branch points. ${ }^{2}$

The swelling and the solubilization of starch molecules have an influence on the rheological behavior of the starch gel. An increase in the rigidity of starch dispersions at $42 \%$ and $47 \%(\mathrm{w} / \mathrm{w})$ moisture contents was observed in corn, wheat and potato starch. The rigidity is attributed to the swelling of the starches. ${ }^{3}$

Swelling accompanying water sorption causes progressive or sometimes abrupt changes in sorption behavior as a result of structural alterations and the possible exposure of new sites with high affinity for water. ${ }^{4}$ The swelling power of starch indicates the degree of water absorption of starch granules during the starch swelling procedure. ${ }^{5}$ When starch granules are heated with sufficient water, the crystalline structure of starch is disrupted, which causes increased granule swelling.

Field-flowfractionation (FFF) is a family of techniques applicable to separation and characterization of various types of macromolecules and particles in the size range of a few nanometers up to a few tens of microns. ${ }^{6}$ Gravitational field-flow fractionation (GrFFF) is one of simpler versions of the FFF family, and is relatively easy to build and simple to operate. ${ }^{7} \mathrm{GrFFF}$ has been used for separation and sizing of various types of micron-sized particles including blood cells, ${ }^{8,9}$ silica particles, ${ }^{10}$ starch granules, ${ }^{11}$ yeast, ${ }^{12,13}$ pollens, ${ }^{14}$ stem cell ${ }^{15}$ and bacteria. ${ }^{16}$

In this study, the starch granules were isolated from starch powder and then their change of size was monitored by GrFFF. The GrFFF results were compared with those obtained by optical microscopy (OM).

\subsection{Theory}

In GrFFF, the retention time, $t_{r}$ of particles having diameter, $d$, is given by ${ }^{17}$

$$
\mathrm{t}_{\mathrm{r}}=\frac{\mathrm{wt}^{\mathrm{o}}}{3 \gamma \mathrm{d}}
$$

where $w$ is the channel thickness, $t^{o}$ the channel void time, and $\mathrm{g}$ a dimensionless "steric correction factor. If $\gamma$ is assumed to be a constant, $t_{r}$ is inversely proportion to $d$. Thus GrFFF can provide size-based separations, where larger particle elute earlier than smaller particles. Due to the uncertainty in $\gamma$, the size analysis by GrFFF requires a calibration ( $\log t_{r}$ vs. $\log d$ ). The GrFFF calibration curve is usually linear, and is expressed by ${ }^{18}$

$$
\log \mathrm{t}_{\mathrm{r}}=-\mathrm{S}_{\mathrm{d}} \log \mathrm{d}+\log \mathrm{A}
$$

where $A$ is a constant equal to the extrapolated value of the retention time for the particle of unit diameter. The slope of the calibration curve $\left(\mathrm{d} \log t_{r} / \mathrm{d} \log d\right)$ is defined as the size-based selectivity, $S_{d}$. Assuming the band broadening, a GrFFF fractogram can be transformed into a size distribution by ${ }^{18}$

$$
\mathrm{m}(\mathrm{d})=\mathrm{c}\left(\mathrm{t}_{\mathrm{r}}\right) \dot{\mathrm{V}} \mathrm{S}_{\mathrm{d}} \mathrm{A}\left(\frac{\mathrm{t}_{\mathrm{r}}}{\mathrm{A}}\right)^{\frac{\mathrm{S}_{\mathrm{d}}+1}{\mathrm{~S}_{\mathrm{d}}}}
$$

where $m(d)$ is the mass-based size distribution, $c\left(t_{r}\right)$ the fractogram signal (detector response), and $\dot{V}$ the volumetric flow-rate through the channel.

\section{Experimental}

\subsection{Materials}

Potato starch and sweet potato starch powder were obtained from Mok-Hwa Food Co. (Cheonan, Korea). 


\subsection{Sample preparation}

Samples were prepared using a similar method as that used in previous publications. ${ }^{19}$ Starch powder was mixed with $1: 7 \mathrm{v} / \mathrm{v}$ mixture of toluene and water containing $0.2 \mathrm{M} \mathrm{NaCl}$ for 12 hours at room temperature. Then the starch suspension was filtered through a sieve having pore diameter of $70 \mu \mathrm{m}$. Starch with the residue of endosperm was extracted into the aqueous phase. The toluene layer contained undesirable proteins. The starch granules trapped in the toluene/water layer were retrieved by washing with distilled water followed by centrifugation and added to the aqueous phase. After washing three times (re-suspension and centrifugation at 3000 rpm for $20 \mathrm{~min}$ ) with distilled water, the starch granule suspension was filtered through a sieve with pore diameter of $44 \mu \mathrm{m}$. The brown protein/ cell wall residue of an endosperm remained on the sieve. The starch suspension was centrifuged at $3000 \mathrm{rpm}$ for $20 \mathrm{~min}$, then washed three times with acetone (blow organic solvent) and then dried at room temperature.

\subsection{Optical microscopy (OM)}

The optical microscopy (OM) was performed by using an Olympus BX51TF optical microscopy (Shinjuku Monolith, Shinjuku-ku, Japan). For all OM analysis of the particles, 500 1,000 beads were measured by using the Image Inside software (Focus, Daejeon, Korea).

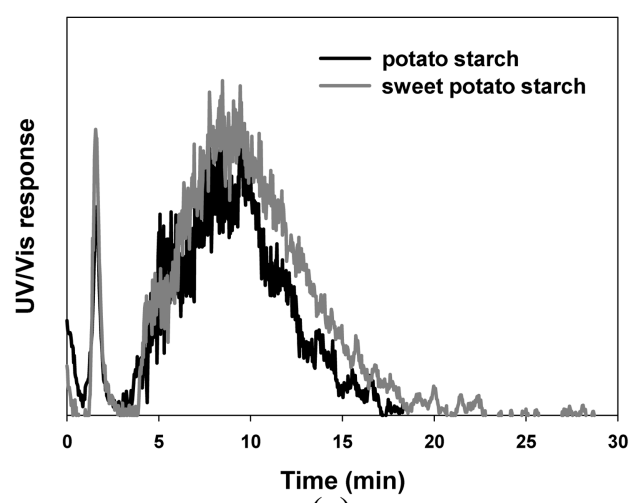

(a)

\subsection{Gravitational field-flow fractionation (GrFFF)}

The GrFFF channel was cut in $200 \mu$ m-thick Mylar spacer and inserted between two glass plates. The channel dimensions were $50 \times 2 \mathrm{~cm}$. The carrier liquid was supplied by a Young-Lin SP930D HPLC pump (Seoul, Korea). The particles in the FFF eluent were monitored by a Young-Lin M720 UV detector at the wavelength of $254 \mathrm{~nm}$. The carrier liquid was water containing $0.02 \% \quad \mathrm{NaN}_{3}$ and $0.1 \%$ FL-70. The sample was introduced into the channel via an inlet capillary situated at the channel head, and taken out via an outlet capillary located at the end of the channel. For the sample preparation studies, the granules were suspended in deionized water and then, sonicated for $5 \mathrm{~min}$. A linear flow was then applied at a flow rate $1.4 \mathrm{~mL} / \mathrm{min}$, concentration of sample is $1.2 \%$. Injected volume of sample was 20 $\mu \mathrm{L}$. Sampling was performed at different days after the inoculation process. A stop-flow time of $6 \mathrm{~min}$ was applied for sample relaxation.

\section{Results and Discussion}

\subsection{GrFFF channel calibration}

To calibrate GrFFF channel, polystyrene latex particles of known particle sizes were used. To optimize flow-rate condition, polystyrene latex particles were eluted at six different flow rates of 1, 1.2, 1.4, 1.6, 1.8 and $2 \mathrm{~mL} / \mathrm{min}$, respectively. Among various flowrate tested, the $1.4 \mathrm{~mL} / \mathrm{min}$ flow-rate was chosen as

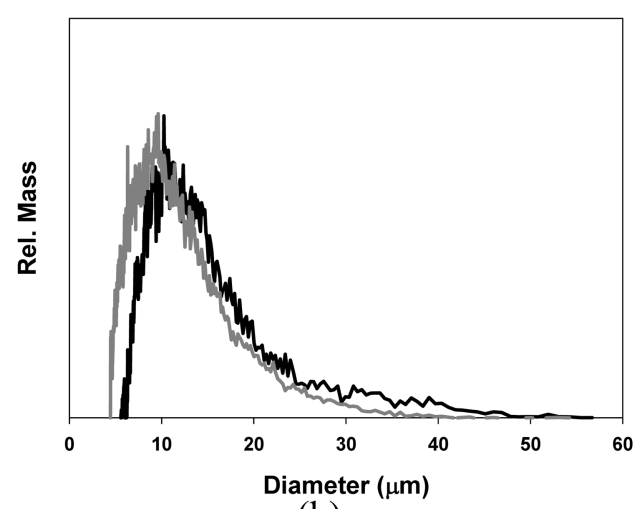

(b)

Fig. 1. GrFFF fractograms (a) and mass-based size distribution (b) of original potato and sweet potato starch granules. 
it yielded the highest $R^{2}$ and fast separation efficient (data not shown). Calibration function was obtained as follow: $\log t_{r}=-0.7562 \log d+0.9878, R^{2}=0.9878$; where $t_{r}$ is the retention time and $d$ is diameter value.

\subsection{Size distributions of potato and sweet} potato starch granules by GrFFF and OM

Fig. 1(a) shows a GrFFF fractograms of the potato and sweet potato starches at the same experimental condition as explained in section 3.1. As explained with Eq. (3), the GrFFF fractogram can be directly converted to a size distribution. The size distributions converted from the fractograms shown in Fig. 1(a) are shown in Fig. 1(b). The size distributions of potato and sweet potato starch in Fig. 1(b) shows a broad size distribution range from 4 to $50 \mu \mathrm{m}$. The size distributions of starches obtained from $\mathrm{GrFFF}$ were compared with OM distributions as shown in Fig. 2. It can be seen that both starches broad size distributions with the average sizes of 20.7 and 16.8 $\mu \mathrm{m}$ for the potato and the sweet potato starch, respectively.

\subsection{Effect of storage time on starch swelling}

The swelling of starch granules caused by watersorption causes progressive or sometimes abrupt changes in sorption behavior as a result of structural alterations and the possible exposure of new sites with high affinity for water. It is thus of interest to examine the change in size or shape of the starch granules with time.

To investigate the effect of the storage time on

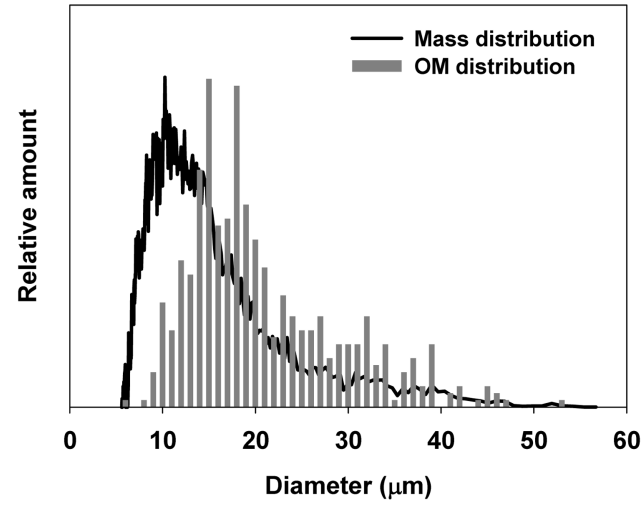

(a)

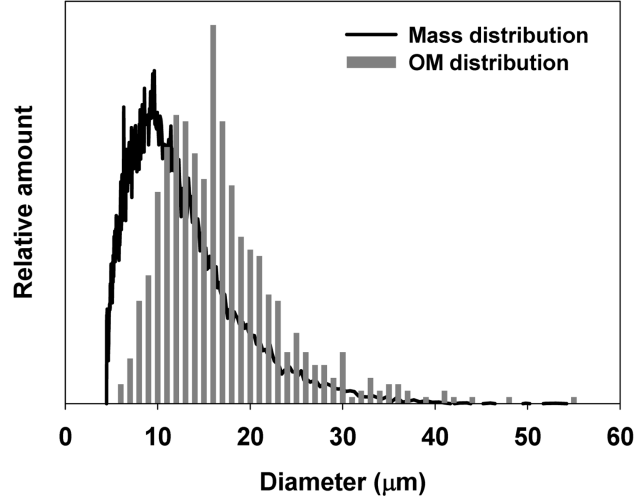

(b)

Fig. 2. Mass-based size distributions of potato (a) and sweat potato (b) obtained by GrFFF (line) and optical microscopy (bars).

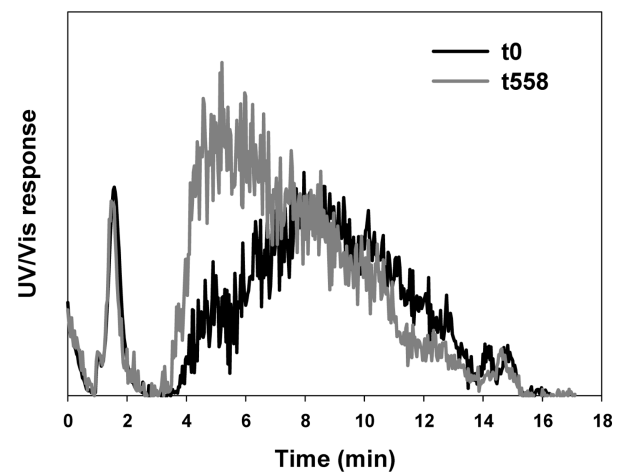

(a)

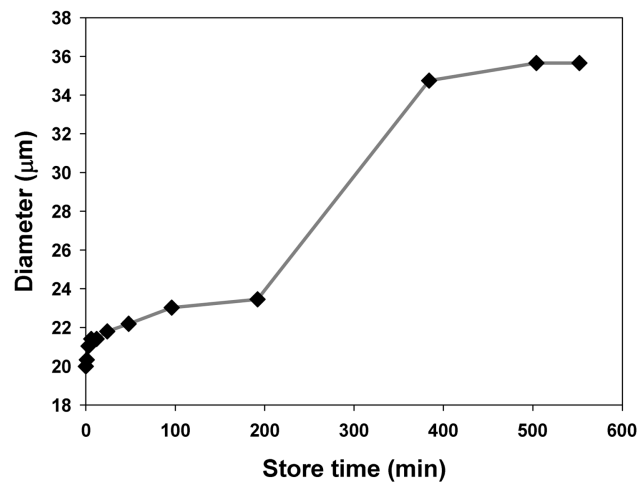

(b)

Fig. 3. GrFFF fractograms of sweat potato starch with two different storage times ( 0 and $558 \mathrm{hrs}$ ) (a) and plot of $d$ obtained from the peak maximum of GrFFF fractograms vs. storage time (b). 
swelling of starch, the starch samples were stored for various durations at room temperature. Fig. 3(a) shows two GrFFF fractograms of sweet potato starch obtained after storage times of $0\left(t_{\mathrm{o}}\right)$ and $558\left(t_{\mathrm{o}}\right)$ min. After the storage time of $558 \mathrm{~min}$, the overall elution time of the sweet potato starch was reduced as compared to that of unswollen sample $\left(t_{\mathrm{o}}\right)$, indicating the sizes of the starch granules grew due to swelling. The change in size of the starch granule is shown in Fig. 3(b) as a plot of the diameter vs. storage time. In Fig. 3(b), the diameters were determined for the peak maxima of the fractograms. It can be seen in Fig. 3(b), that the size gradually increases with the storage time. It is interesting to see that the sweet potato starch granules are mostly swollen during the storage time of between 200 and $400 \mathrm{~min}$

These results were compared with those obtained from optical microscopy (OM) images of sweet potato starch granules shown in Fig. 4. Fig. 4(a)-(c)
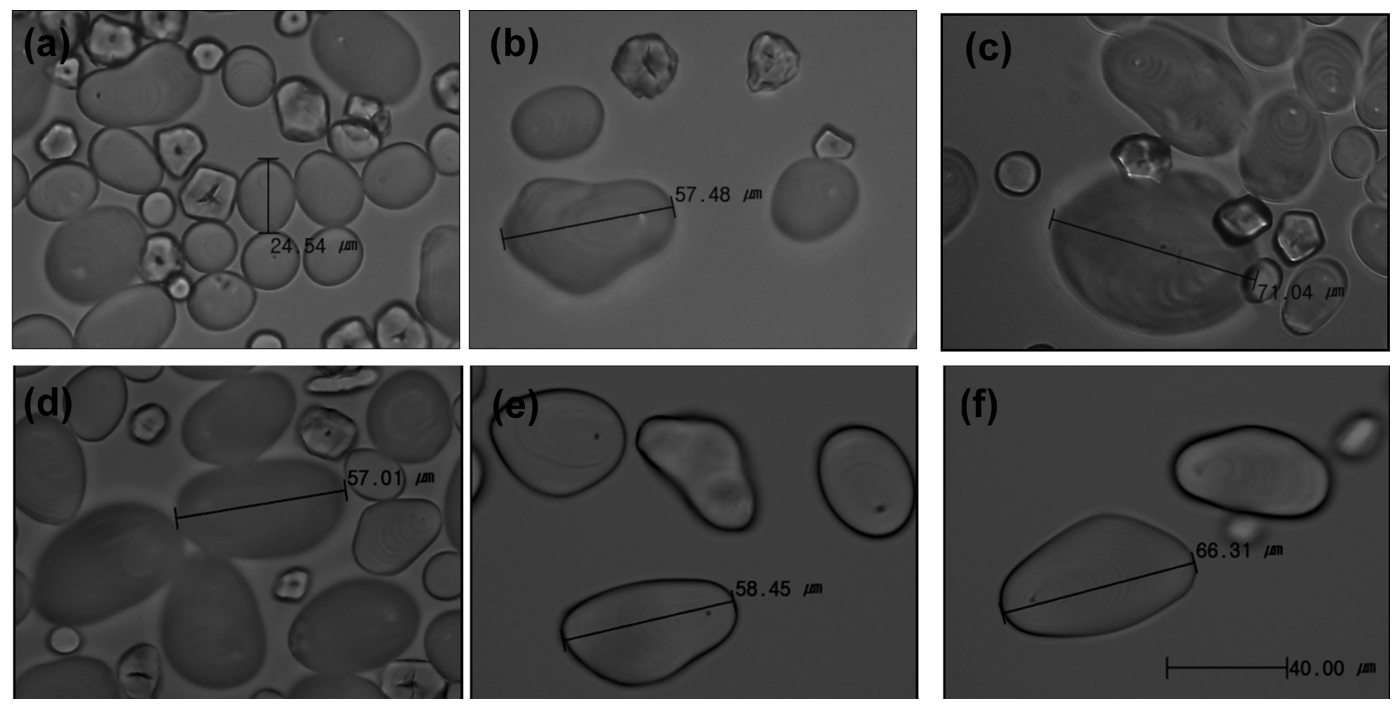

Fig. 4. Optical microscopy (OM) images of sweet potato starch granules; (a) $t_{0}$; (b) $t_{6}$; (c) $t_{192}$; (d) $t_{384}$; (e) $t_{504}$; (f) $t_{552}$.
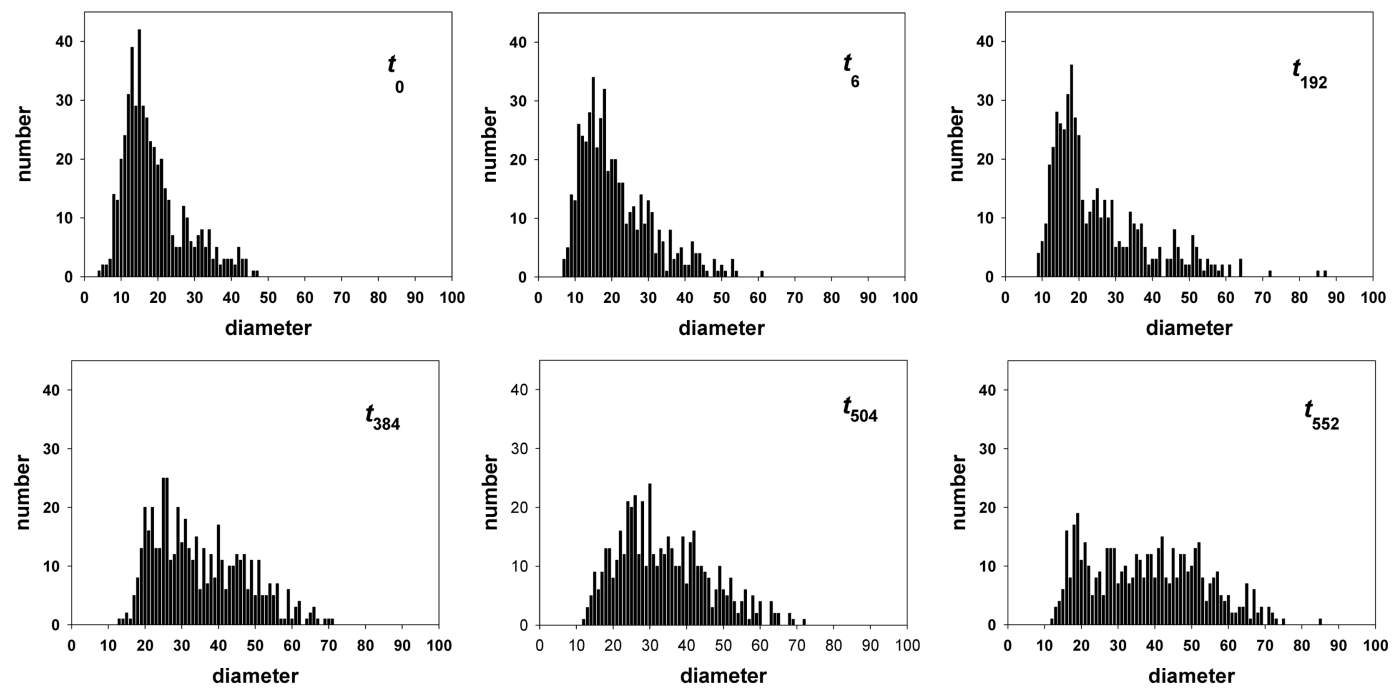

Fig. 5. OM size distributions of sweet potato starch granules. 


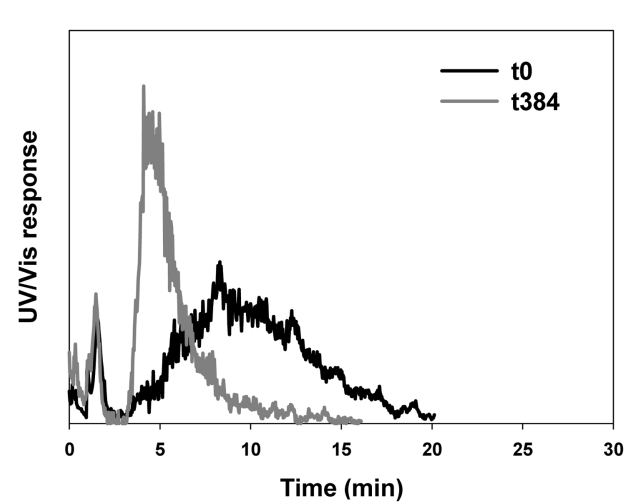

(a)

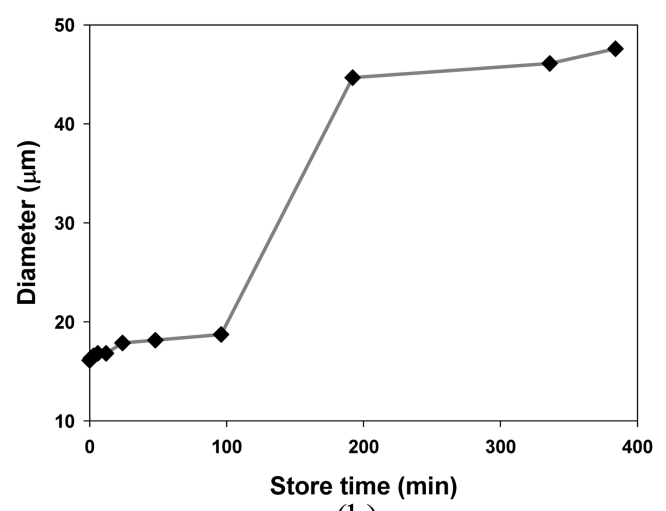

(b)

Fig. 6. GrFFF fractograms of potato starch with two different storage times ( 0 and 384 hrs) (a) and plot of $d$ obtained from the peak maximum of GrFFF fractograms vs. storage time (b).
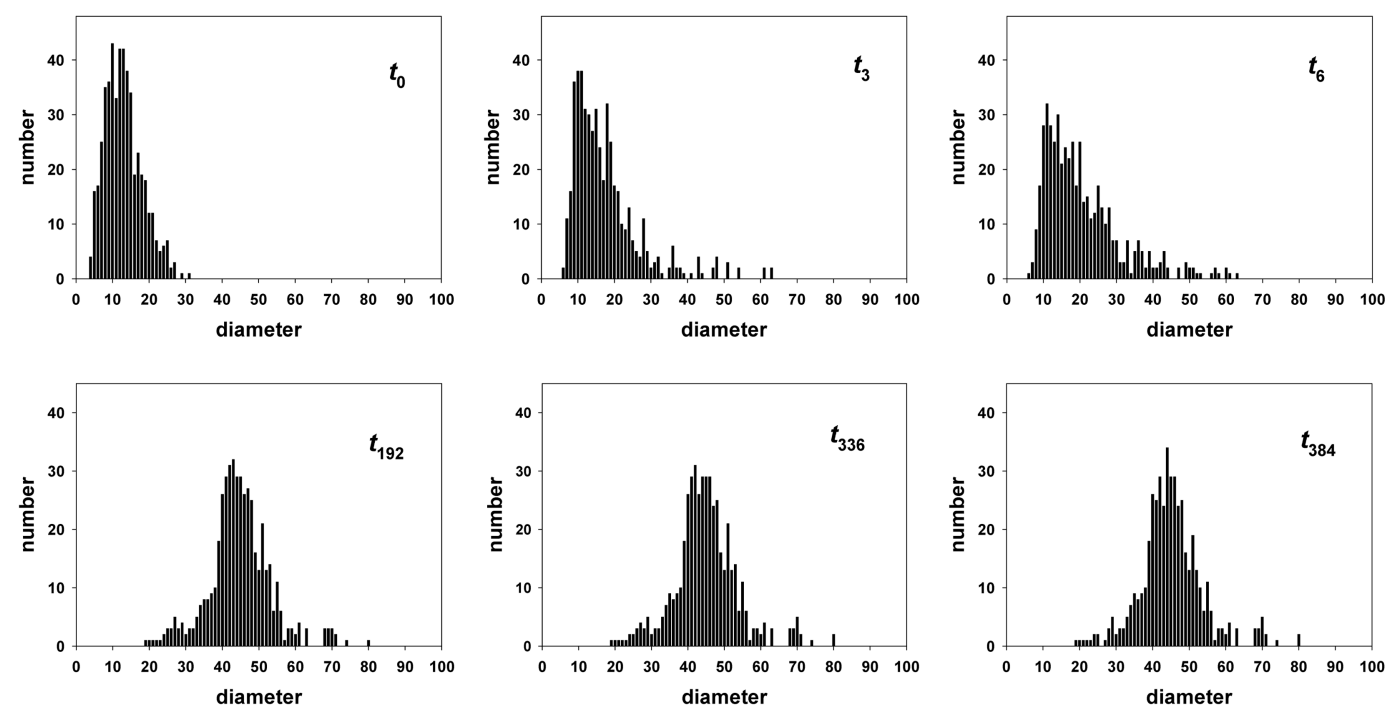

Fig. 7. OM size distributions of potato starch granules; (a) $t_{0}$; (b) $t_{3}$; (c) $t_{6}$; (d) $t_{192}$; (e) $t_{336}$; (f) $t_{384}$.

shows photographs of the $t_{0}$ to $t_{192}$ samples. It is seen that the granules of sweet potato increase in size after $192 \mathrm{~min}\left(t_{192}\right)$ as shown in Fig. 4(d)-(f).

The size distributions of sweet potato granules shown in Fig. 4 are shown in Fig. 5. Generally the OM size distributions show similar tend as those obtained from GrFFF shown in Fig. 3(b), where the granule sizes increase with the storage time due to increased degree of swelling.

Fig. 6 shows the same type of plots as those shown in Fig. 3. This time the sample was the potato starch granules. Similar results as those shown in Fig. 3 were observed, where the sizes of the starch granules increase with the storage time. It seems that the potato starch granules are more quickly swollen than the sweet potato starch granules. The potato starch granules are mostly swollen during the storage time of between 100 and $200 \mathrm{~min}$, while the sweet potato starch granules are between 200 and $300 \mathrm{~min}$. This difference of swelling rate between the potato and the sweet potato starch granules is likely due to the difference in the relative content of the amylase and the amylopectin. The sweet potato is consisted of $20 \%$ amylase and $80 \%$ amylopectin, while the potato is of $23 \%$ amylase and $77 \%$ amylopectin, respectively. The size distributions of each storage 
time shown in Fig. 7. It seems that the relative content of the amylase and amylopectin in starch granule is one of important factors determining the swelling rate.

\section{Conclusion}

GrFFF provides the size-based separation of micronsized potato and sweet potato starch granules. GrFFF yielded the mean size that is in reasonable agreements with the results from optical microscopy (OM). GrFFF was rather successfully applied for investigation of the swelling behavior of the starch granules such as the swelling rate and the size increase, etc. GrFFF could be a useful tool for monitoring of the other types of the starch granules.

\section{Acknowledgements}

Authors acknowledge the support from Hannam University.

\section{References}

1. J. R. Stark and A. Lynn, Biochem. Soc. Trans., 20, 7-12 (1992).

2. A. Buleon, P. Colonna, V. Planchot and S. Ball, Int. J. Biol. Macromol., 23, 85-112 (1998).

3. A. Rolee and M. Le Meste, Cereal Chem., 74, 581-588 (1997).

4. E. C. Lopez, A. Rolee and M. Le Meste, Starch-Starke, 56, 576-581 (2004).
5. M. Carcea and R. Acquistucci, Starch-Starke, 49, 131135 (1997).

6. M. Martin and J. C. Giddings, J. Phys. Chem., 85, 727733 (1981)

7. J. C. Giddings and M. N. Myers, Sep. Sci. Technol., 13, 637-645 (1978).

8. A. Bernard, C. Bories, P. M. Loiseau and P. J. P. Cardot, J. Chromatogr. B, 664, 444-448 (2001).

9. S. Rasouli, E. Assidjo, T. Chianea and P. J. P. Cardot, J. Chromatogr. B, 754, 11-21 (2001).

10. P. Reschiglian, D. Melucci, G. Torsi and A. Zattoni, Chromatographia, 51, 87-94 (2000).

11. J. Janouskova, M. Budinska, J. Plockova and J. Chmelik, J. Chromatogr. A, 914, 183-187 (2001).

12. R. Sanz, L. Puignou, P. Reschiglian and M. T. Galceran, J. Chromatogr. A, 919, 339-347 (2001).

13. R. Sanz, L. Puignou, M. T. Galceran, P. Reschiglian, A. Zattoni and D. Melucci, Anal. Bioanal. Chem, 379, 1068-1075 (2004).

14. D. Y. Kang, M. S. Son, C. H. Eum, W. S. Kim and S. Lee, Bull. Kor. Chem. Soc., 28, 613-618 (2007).

15. E. Urbankova, A. Vacek and J. Chemelik, J. Chromatogr. $B, 687,449-452$ (2007).

16. P. Reschiglian, A. Zattoni, B. Roda, S. Casolari, M. H. Moon, J. Lee, J. Jung, K. Rodmalm and G. Cenacchi, Anal. Chem., 74, 4895-4904 (2002).

17. J. C. Giddings, Sep. Sci. Technol., 13, 241-254 (1978).

18. J. C. Giddings, M. H. Moon, P. S. Williams and M. N. Myers, Anal. Chem., 63, 1366-1372 (1991).

19. J. Chmelik, A. Krumlova, M. Budinska, T. Kruml, V. Psota, I. Bohacenko, P. Mazal and H. Vydrova, J. Inst. Brew., 107, 11-17 (2001). 